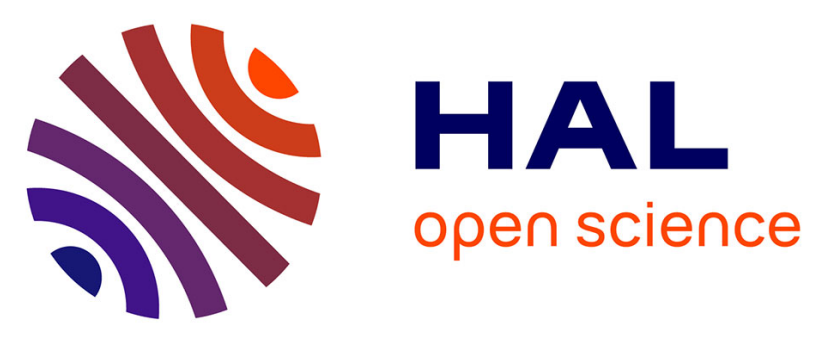

\title{
Prenatal stress and early-life exposure to fluoxetine have enduring effects on anxiety and hippocampal BDNF gene expression in adult male offspring
}

Fabien Boulle, Jodi L. Pawluski, Judith R. Homberg, Barbie Machiels, Yvet Kroeze, Neha Kumar, Harry W. M. Steinbusch, Gunter Kenis, Daniel L. A van Den Hove

\section{To cite this version:}

Fabien Boulle, Jodi L. Pawluski, Judith R. Homberg, Barbie Machiels, Yvet Kroeze, et al.. Prenatal stress and early-life exposure to fluoxetine have enduring effects on anxiety and hippocampal BDNF gene expression in adult male offspring. Developmental Psychobiology, 2016, 58 (4), pp.427-438. 10.1002/dev.21385 . hal-01305478

\section{HAL Id: hal-01305478}

\section{https://hal-univ-rennes1.archives-ouvertes.fr/hal-01305478}

Submitted on 5 Jul 2016

HAL is a multi-disciplinary open access archive for the deposit and dissemination of scientific research documents, whether they are published or not. The documents may come from teaching and research institutions in France or abroad, or from public or private research centers.
L'archive ouverte pluridisciplinaire HAL, est destinée au dépôt et à la diffusion de documents scientifiques de niveau recherche, publiés ou non, émanant des établissements d'enseignement et de recherche français ou étrangers, des laboratoires publics ou privés. 
Running head: Developmental SSRIs, anxiety and BDNF 


\section{Prenatal stress and early-life exposure to fluoxetine have enduring effects on anxiety and hippocampal BDNF gene expression in adult male offspring}

Fabien Boulle ${ }^{\mathrm{a}, \mathrm{b} *}$, Jodi L Pawluski ${ }^{\mathrm{a}, \mathrm{c} *}$, Judith R Homberg ${ }^{\mathrm{d}}$, Barbie Machiels ${ }^{\mathrm{a}}$, Yvet Kroeze $^{\mathrm{d}}$, Neha Kumar ${ }^{\mathrm{a}}$, Harry WM Steinbusch ${ }^{\mathrm{a}}$, Gunter Kenis ${ }^{\mathrm{a}}$, Daniel LA Van den Hove a,e

*These authors contributed equally to this work

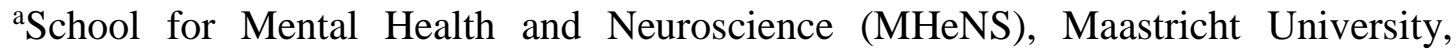
European Graduate School of Neuroscience (EURON), Universiteitssingel 50, P.O. box 616, $6200 \mathrm{MD}$, Maastricht, The Netherlands

${ }^{\mathrm{b} C e n t e r}$ for Psychiatry and Neuroscience, INSERM U894, University Pierre and Marie Curie, Paris, France

'University of Liege, GIGA-Neurosciences, 1 avenue de l'Hôpital (Bat. B36), B-4000 Liège, Belgium

${ }^{\mathrm{d}}$ Donders Institute for Brain, Cognition, and Behaviour, Centre for Neuroscience, Radboud University Medical Centre, Department of Cognitive Neuroscience, Geert Grooteplein 21, 6525 EZ Nijmegen, The Netherlands

eMolecular Psychiatry, Department of Psychiatry, Psychosomatics and Psychotherapy, University of Wuerzburg, Fuechsleinstrasse 15, 97080 Wuerzburg, Germany

\section{Corresponding author:}

Jodi L. Pawluski, Ph.D., University of Rennes 1, Campus Beaulieu Bat 13, Room 135/2, 35042 Rennes Cedex, FRANCE, Phone: +33(0)2 23.23.41.90, Email address: j.pawluski@gmail.com 
With the growing use of selective serotonin reuptake inhibitor medications (SSRIs) for the treatment of depression during the perinatal period, questions have been raised about the longterm impact of these medications on development. We aimed to investigate how developmental SSRI exposure may alter affect-related behaviors and associated molecular processes in offspring using a rodent model of maternal stress and depression. For this purpose, prenatally stressed or non-stressed male offspring were exposed to fluoxetine $(5 \mathrm{mg} / \mathrm{kg} / \mathrm{day})$ or vehicle, via lactation, until weaning. Primary results show that postnatal fluoxetine exposure differentially altered anxietylike behavior by increasing anxiety in non-stressed offspring and decreasing anxiety in prenatally stressed offspring. In the hippocampus, developmental fluoxetine exposure decreased BDNF IV and TrkB mRNA expression. Prenatal stress alone also decreased escape behaviors and decreased hippocampal BDNF IV mRNA expression. These data provide important evidence for the long-term programming effects of early-life exposure to SSRIs on brain and behavior.

Keywords: SSRI; depression; prenatal stress; neuroplasticity; sex differences; hippocampus; BDNF; TrkB 


\section{$\underline{\text { Introduction }}$}

Selective serotonin reuptake inhibitor medications (SSRIs) are the treatment of choice for mood disorders during pregnancy and the postpartum period, with up to $10 \%$ of pregnant women being prescribed these medications (Cooper, Willy, Pont, \& Ray, 2007; Oberlander, Warburton, Misri, Aghajanian, \& Hertzman, 2006). SSRIs have relatively few side effects for the mother and are not associated with gross teratogenic effects in offspring (Kiryanova, McAllister, \& Dyck, 2013; Malm, 2012). However, SSRIs cross the placental barrier, are evident in the umbilical cord blood, and are present in breast milk (Homberg, Schubert, \& Gaspar, 2010; Kristensen et al., 1999; Rampono, Proud, Hackett, Kristensen, \& Ilett, 2004) and recent clinical studies report that neonates exposed to SSRIs during gestation have an increased risk for complications at birth involving low birth weight, reduced gestational age, and impaired heart rate variability (Moses-Kolko et al., 2005; Oberlander, Gingrich, \& Ansorge, 2009). In addition, clinical reports in infants also show that prenatal exposure to SSRIs may affect neurodevelopment as evidenced by alterations in S100B levels (Pawluski, Galea, Brain, Papsdorf, \& Oberlander, 2009), the serotonergic system functioning (Laine, Heikkinen, Ekblad, \& Kero, 2003), as well as a changes in the hypothalamic-pituitary-adrenal (HPA) system (Oberlander, et al., 2009; Pawluski et al., 2012).

Although there is limited clinical insight in the long-term outcomes of developmental exposure to SSRIs on mood disorders in adulthood, prenatal exposure to SSRIs can impact affect-related behaviors in children (Misri et al., 2006; Oberlander et al., 2010; Oberlander et al., 2007). For example, 4 year old children, exposed prenatally to SSRIs, have higher scores of externalizing behaviors, such as aggression, attention/hyperactivity, and oppositional or defiant behaviors, than the clinical cutoff (Oberlander, et al., 2007). In addition, exposure to both prenatal SSRIs and maternal depression can increase internalizing behaviors (depression, anxiety, and withdrawal) in 3 and 4 year olds (Oberlander, et al., 2010). Preclinical studies have also demonstrated that developmental SSRI exposure can have long term effect on affective-like behaviors in offspring with a well-documented increase in both anxietyand depression-related behaviors, particularly in adult male offspring, after prenatal or early postnatal treatment with SSRIs (Ansorge, Zhou, Lira, Hen, \& Gingrich, 2004; Karpova, Lindholm, Pruunsild, Timmusk, \& Castren, 2009; Lisboa, Oliveira, Costa, 
Venancio, \& Moreira, 2007; Noorlander et al., 2008; Olivier et al., 2011; Popa, Lena, Alexandre, \& Adrien, 2008; Smit-Rigter et al., 2012), however, this is not always the case and often minimal long-term effects of perinatal SSRI exposure has been reported (Nagano, Liu, Inagaki, Kawada, \& Suzuki, 2012; Pereira-Figueiredo, Sancho, Carro, Castellano, \& Lopez, 2014). It should be noted that the majority of these studies did not investigate the effect of perinatal SSRI exposure using a model of maternal depression.

Interestingly, recent research is showing that developmental SSRI exposure can reverse the effects of maternal stress, as a model of maternal depression (O'Mahony et al., 2006), on depressive- and anxiety-like behaviors, at least in male rat offspring (Nagano, et al., 2012; I. Rayen, van den Hove, Prickaerts, Steinbusch, \& Pawluski, 2011) suggesting a potentially beneficial effect of perinatal SSRI exposure on development. Using a model of maternal stress and depression with SSRI exposure also more closely mimics the clinical situation and allows for further understanding of the effects of maternal stress/depression and SSRIs on development. Much more research is needed in this area.

The molecular pathways underlying the long-term behavioral effects of earlylife SSRI exposure on mood are poorly understood. Research has shown that there are significant changes in hippocampal plasticity after exposure to SSRIs in adolescent and adult rat offspring (Ine Rayen, Gemmel, Pauley, Steinbusch, \& Pawluski, 2015; I. Rayen, et al., 2011) and it is likely that these effects are related to changes in brainderived neurotrophic factor (BDNF) as well as BDNF and tropomyosin-related kinase receptor B (TrkB) signaling pathways. BDNF is critically involved in the regulation of neuronal plasticity, and alterations of BDNF signaling have been extensively implicated in the pathophysiology and treatment of mood disorders such as anxiety and depression (Castren \& Rantamaki, 2010). Accordingly, a recent study showed that early postnatal administration of fluoxetine, a popular SSRI used during the perinatal period, could induce long-lasting behavioral impairment, accompanied with changes in hippocampal BDNF mRNA levels in adult male mice (Karpova, et al., 2009), BDNF protein levels in adult male rats (Nagano, et al., 2012) and global DNA methylation in the hippocampus (Toffoli et al., 2014). Similarly, epigenetic changes at the BDNF gene in adulthood have been associated with mood disorders (Boulle et al., 2012). Furthermore, serotonin transporter (5-HTT) knockout rats, which display high levels of serotonin (5HT), have lower levels of hippocampal BDNF, concomitant with 
epigenetic dysregulation at the BDNF gene - i.e. increased DNA methylation at BDNF promoters IV and VI (Molteni et al., 2010). Further work is needed to determine how long-term behavioral changes related to developmental SSRI exposure may modulate hippocampal BDNF signaling.

The aim of the present study was to investigate the long-term molecular and behavioral consequences of developmental administration of fluoxetine. Since perinatal maternal stress and depression itself can have marked effects on the development of mood disorders and stress regulation (Maccari \& Morley-Fletcher, 2007; Van den Hove et al., 2013), it is important to investigate the effects of SSRIs using a model of maternal depression (Pawluski, 2012; Van den Hove et al., 2008). Hence, we explored the effects of maternal fluoxetine during a time of rodent neural development that is analogous to SSRI exposure to human neonates beginning during the third trimester (Romijn, Hofman, \& Gramsbergen, 1991), using a well-established model of prenatal restraint stress in Sprague-Dawley rats (Van den Hove et al., 2006; Weinstock, 2008), and focused particularly on measures related to affective behaviors and regulation of hippocampal BDNF signaling in adult male offspring. We expected to see a long-term impact of developmental SSRI exposure on affect-related behavior as well as hippocampal BDNF signaling that would be modified when using a model of prenatal stress as a model of maternal depression (Leuner, Fredericks, Nealer, \& Albin-Brooks, 2014).

\section{$\underline{\text { Methods }}$}

$\underline{\text { Animals }}$

Experiments were approved by the Animal Ethics Board of Maastricht University in accordance with Dutch governmental regulations (DEC 2008-157 and 2008-158), the European Communities Council Directive (86/609/EEC). All efforts were made to minimize the pain and stress experienced by the animals, to minimize the number of animals used and to utilize alternatives to in vivo techniques, if available.

Thirty-eight adult female Sprague-Dawley rats (250-300 g; Charles River Laboratories, France) and twenty adult male Sprague-Dawley rats (Charles River Laboratories, France) were used in the present study for breeding. These animals were 
initially housed in pairs in opaque polyurethane bins $(48 \mathrm{~cm} \times 27 \mathrm{~cm} \times 20 \mathrm{~cm})$ with ad libitum access to rat chow (Sniff, The Netherlands) and tap water and were kept under standard laboratory conditions in a $12 \mathrm{~h}: 12 \mathrm{~h}$ light/dark schedule (lights on at 07:00h). Dams were bred by putting 1 female and 1 male together in a wire mesh cage and pregnancy was determined by observation of vaginal plugs (embryonic day 0 E0). Dams were randomly assigned to stress or control groups on GD14 and restraint of dams in the stress group took place three times daily in transparent plastic cylinders under bright light for $45 \mathrm{~min}$ (between $8-10 \mathrm{am}, 12-2 \mathrm{pm}, 4-6 \mathrm{pm}$ ) as previously described between GD15-GD21 (Van den Hove et al., 2005; Ward \& Weisz, 1984). Stress during late pregnancy can result in postpartum depressive-like behavior in the dam (Leuner, et al., 2014; O'Mahony, et al., 2006; Smith, Seckl, Evans, Costall, \& Smythe, 2004) and, thus, this paradigm was used to model aspects of maternal postpartum depression as previously described (Leuner, et al 2014).

The day after birth (PD1) litters were culled to 5 males and 5 females (birth day = P0) and dams and litters were randomly assigned to one of two treatment groups: fluoxetine $(5 \mathrm{mg} / \mathrm{kg} / \mathrm{day})$ or vehicle, for a total of four groups offspring: (1) No stress + Vehicle (NS VEH) $(n=14),(2)$ No stress + Fluoxetine (NS FLX) $(n=13)$, (3) Prenatal Stress + Vehicle (PNS VEH) $(n=15)$, (4) PNS + Fluoxetine (PNS FLX) $(n=14)$. Weaning occurred on P21, followed by housing of litter groups in clear polyutherane bins $(48 \mathrm{~cm} \times 27 \mathrm{~cm} \times 20 \mathrm{~cm})$. One week later offspring were housed in same sex litter pairs until sacrifice (P196). Offspring were housed in the reverse light cycle (lights off at 7am) beginning at least 2 weeks prior to behavioral testing. Only male offspring were used in the present study. Female offspring were used in an additional work (Boulle et al, under review). A maximum of two adult male offspring per litter were chosen at random and used in the present study. Additional offspring were used in other studies.

\section{$\underline{\text { Fluoxetine exposure }}$}

Fluoxetine treatment to the dam was administered via osmotic minipumps (Alzet Osmotic pumps, 2ML4, Cupertino CA, USA) during the postpartum period as previously described (Oliveira et al., 2010; I. Rayen, et al., 2011). Osmotic minipumps were implanted subcutaneously in the dorsal region (upper back) of the dam on P1 using mild isofluorane anesthesia. Implants took a maximum of 20 
minutes and offspring were separated from their mother for a maximum of 20 minutes, but were housed in the same room as the dam. Minipumps were filled with either fluoxetine (Fagron, Belgium) dissolved in vehicle (50\% propylenediol in saline; $5 \mathrm{mg} / \mathrm{kg} /$ day), or with vehicle as previously described (Alahmed \& Herbert, 2008; Ine Rayen, et al., 2015; I. Rayen, Steinbusch, Charlier, \& Pawluski, 2013, 2014).

Fluoxetine, and its active metabolite, norfluoxetine, are present in breast milk and can pass to offspring through lactation (Gentile, 2004, 2005; Gentile, Rossi, \& Bellantuono, 2007; Kristensen, et al., 1999). Administration of fluoxetine in this method and during the early postpartum period results in detectable levels of fluoxetine and its active metabolite, norfluoxetine, in serum of mother and pups (Knaepen et al., 2013). These implants also reduce the effect of stress associated with repeated injections or oral gavage. Fluoxetine exposure to offspring occurred during a stage of neural development in rodents analogous to that of the third trimester and early postnatal period in humans (Romijn, et al., 1991).

\section{$\underline{\text { Behavioral testing }}$}

On P140 adult male offspring were subject to behavioral tests in the following order; the open field test, elevated zero maze, the forced swim test and corticosterone response to stress. There was 1 week between tests. Testing occurred between 9am and noon in the reversed light cycle.

The open field test (OFT). The OFT consisted of a square plexiglass base (100 x 100 $\mathrm{cm}$ ) with a black floor and transparent plexiglass walls as previously described (Van den Hove, et al., 2013). Immediately after the rat was placed in the centre of the open field, the movements of the rat were scored automatically for 5 minutes using a camera connected to a computerized system (Ethovision Pro, Noldus, The Netherlands). Testing was done under low light conditions. Both the time spent in the peripheral and central zones and total distance moved was scored.

The elevated zero maze (EZM). The EZM consisted of a circular alley (diameter of $100 \mathrm{~cm}$; path width $10 \mathrm{~cm}$ ) made from black plexiglass material that was transparent for infrared light and elevated $20 \mathrm{~cm}$ above the floor as previously described (Van den Hove, et al., 2013). For the test, the rat was placed into one of the open arms facing a closed arm of the apparatus. The movements of the rat were scored automatically 
under dark conditions with a computerized system using an infrared video camera (Ethovision Pro, Noldus, The Netherlands). Time spent in the open part of the maze and total distance traveled were determined as described previously (Van den Hove, et al., 2013). An open arm entry was when the center of the animal's body and front two paws entered an open arm.

The forced swim test (FST). Testing in the FST used cylindrical plexiglass tanks (50 $\mathrm{cm}$ tall, $20 \mathrm{~cm}$ in diameter) filled to a height of $30 \mathrm{~cm}$ with $25^{\circ} \mathrm{C}$ water. The movements of the rat were scored automatically with a computerized system (Ethovision Pro, Noldus, The Netherlands) during a 10 min session under low light conditions. Scored behaviors were 'immobility', which reflects no movement at all and/or minor movements necessary to keep the nose above the water; 'mobility', reflecting movement that correspond to swimming activity; and 'strong mobility', reflecting 'escape behavior' (e.g. climbing against the walls and diving). Settings within Ethovision were adjusted based on manually recorded sessions (immobility/mobility threshold: 12; mobility/strong mobility threshold: 16.5 (Strackx et al., 2009; Van den Hove, et al., 2013).

Corticosterone response to stress. Corticosterone response to stress was tested by individually placing offspring in a type II (mouse) cage filled with $500 \mathrm{ml} 25^{\circ} \mathrm{C}$ water. Immediately after taking the rat from its home cage, a first baseline blood sample was collected via a saphenous vein puncture. Immediately after this first sample was taken, the rat was put in the cage filled with water for $20 \mathrm{~min}$ after which a second blood sample was taken. The animal was then returned to its home cage and left undisturbed for $40 \mathrm{~min}$ after which a final blood sample was taken. Experiments were performed in an isolated room between 09.00 and $13.00 \mathrm{~h}$.

Blood samples were kept on ice and centrifuged at $5000 \mathrm{rpm}$ for $10 \mathrm{~min}$ at 4 ${ }^{\circ} \mathrm{C}$. Plasma was stored at $-80^{\circ} \mathrm{C}$ for determination of corticosterone levels. Samples on a subset of animals ( $n=5-6 /$ group) were run in duplicate using a commercially available RIA kit for rat corticosterone (corticosterone I-125 for rats and mice, MP Biomedicals, Santa Ana CA, USA), as explained previously (Pawluski, Charlier, Lieblich, Hammond, \& Galea, 2008). The average intra- and inter-assay coefficients of variation for all assays were below $10 \%$. The assay had a sensitivity of $7.7 \mathrm{ng} / \mathrm{mL}$. 
Cross reactivity with metabolites is as follows; corticosterone $100 \%$, desoxycorticosteorne $0.34 \%$, Testosterone $0.10 \%$, Cortisol $0.05 \%$, Aldosterone $0.03 \%$, Progesterone $0.02 \%$, Androstenedion and 5alpha-dihydrotestosteorne $0.01 \%$.

\section{Histology.}

One week after the last behavioral test (PND 196), offspring were rapidly decapitated. Hippocampi were extracted, immediately frozen in liquid nitrogen and stored at -80C. For analysis, both hippocampi from the same animal were pooled together.

Quantitative reverse transcriptase $P C R(q R T-P C R)$. BDNF/TrkB signaling has been reported as a central player in the mechanism of action of SSRI, as well as in neurodevelopment (Autry \& Monteggia, 2012). Therefore, we chose to study a subset of genes involved at various levels in the hippocampal BDNF/TrkB signaling pathway and known to be implicated in antidepressant responses and/or psychiatric phenotypes (Duman \& Voleti, 2012; Rivero et al., 2013; Stragier et al., 2014; Van den Hove, et al., 2013). These genes are listed in Table 1.

Total mRNA extraction was performed on hippocampal tissues using RNeasy lipid tissue mini kit (Qiagen, Venlo, The Netherlands). Following this, cDNA synthesis was performed using a First Strand cDNA synthesis kit (Fermantas International Inc. Canada) according to the manufacturer's protocol. Amplification was performed using SYBR green I Master Mix (Roche Diagnostic, IN, USA). Selected genes and primer sequences are indicated in Table 1. Gene expression analysis was performed with the LightCycler 480 Real-Time PCR System (Roche Applied Science, IN, USA) and the conditions for the reaction involved 35 cycles in a fixed sequence of $95^{\circ} \mathrm{C}$ for $30 \mathrm{~s}, 62^{\circ} \mathrm{C}$ for $15 \mathrm{~s}$, and $72^{\circ} \mathrm{C}$ for $15 \mathrm{~s}$. Gene expression was normalized using HPRT and RS27A as reference genes.

\section{$\underline{\text { Statistical analysis }}$}

Analysis of variance tests (ANOVAs) were computed on results of behavioral tests, and all histological measures with condition (prenatal stress/no stress) and treatment (fluoxetine/vehicle) as independent factors. A repeated measures ANOVA was done on corticosterone response to stress. Significant condition by treatment interaction effects were analyzed in more detail by a Fisher LSD post hoc test in order 
to compare the individual groups. Statistical significance was assumed to exist at $\mathrm{p}<$ 0.05. All statistics were carried out using SPSS software version 17 (SPSS Inc, USA).

\section{$\underline{\text { Results }}$}

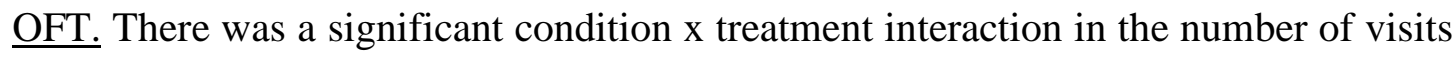
to the center of the open field $(\mathrm{F}(1,52)=5.04 ; \mathrm{p}=0.029$; Figure 1$)$, with fluoxetine decreasing the number of visits to the center in naïve animals and increasing the frequency of visits to the center in prenatally stressed offspring (NS FLX < PNS FLX; $\mathrm{p}=0.024)$. Similarly, regarding the distance traveled within the open field, a tendency towards a condition $x$ treatment interaction was observed $(F(1,52)=3.49 ; p=0.067$; Figure 1), indicating that fluoxetine exposure differentially affected distance traveled in NS versus PNS adult male offspring. There were no other significant differences between groups in additional measures such as the time spent in the centre of the OFT(Figure 1B and Table 3).

EZM. There was strong trend toward a significant condition $\mathrm{x}$ treatment interaction regarding the distance traveled within the $\operatorname{EZM~F}(1,51)=4.04 ; \mathrm{p}=0.049$; Figure 2), where developmental fluoxetine exposure tended to decrease the distance traveled in naïve animals, while it increased the distance traveled in animals exposed to PNS ( $\mathrm{p}=0.093$ ). There were no other significant differences between groups in measures of the EZM such as duration in the open or closed arms(Figure 2 and Table 3).

FST. Among males, a significant effect of PNS on strong mobility was found $(\mathrm{F}(1,51)=4.09 ; \mathrm{p}=0.048 ;$ Figure 3$)$, indicating that PNS decreased escape-like behavior in this behavioral test. There were no other significant differences between groups in immobility or mobility (Figure 3 ).

Corticosterone. As expected, there was a significant main effect of time on corticosterone levels in male offspring $(\mathrm{F}(2,38)=62.750, \mathrm{p}=.00001, \mathrm{n}=5-6 /$ group; Figure 4) showing that $20 \mathrm{~min}$ of restraint stress elevated plasma corticosterone levels. There were no other significant differences in corticosterone levels with treatment $(0.2<\mathrm{p}<0.8)$.

Hippocampal gene expression. There was a significant effect of fluoxetine treatment on BDNF IV and tropomyosin-related kinase receptor B (TrkB) mRNA levels 
$(\mathrm{F}(1,51)=5.57 ; \mathrm{p}=0.022$ and $\mathrm{F}(1,51)=7.21 ; \mathrm{p}=0.0098$ respectively; Figure 5), indicating that developmental fluoxetine exposure decreased BDNF IV and TrkB mRNA levels in both non stressed and prenatal stressed animals. In addition, BDNF IV mRNA levels were decreased in animals exposed to prenatal stress (PNS VEH < NS VEH; $\mathrm{p}=0.041$ ). There was also a tendency towards a stress $\mathrm{x}$ treatment interaction for BDNF IX mRNA levels $(\mathrm{F}(1,51)=4.30 ; \mathrm{p}=0.056$; see Figure 5). There were no other significant differences between groups in related genes investigates (Table 4) and no significant correlations.

\section{$\underline{\text { Discussion }}$}

With the growing use of SSRI antidepressant medication during pregnancy and the postpartum period (Cooper, et al., 2007; Oberlander, et al., 2006) more work is needed to understand the long-term risks and benefits of early-life exposure to these medications. In this context, the aim of the present study was to investigate how early exposure to fluoxetine may alter the effects of maternal stress on anxiety and depression-like behaviors, as well as neurobiological measures related to these behavioral outcomes, in adult male offspring. Our main findings show that postnatal fluoxetine exposure, via the mother, differentially alters anxiety-like behavior by increasing anxiety in non-prenatally stressed offspring and decreasing anxiety in prenatally stressed offspring. Overall, developmental fluoxetine exposure significantly decreased BDNF IV and TrkB mRNA expression in the hippocampus, regardless of prenatal stress exposure. We also found that prenatal stress alone significantly decreased escape behaviors (strong mobility) in the forced swim test and significantly decreased BDNF IV mRNA expression in the hippocampus. Together, these data contribute to our understanding of the long-term programming effects of early-life exposure to prenatal stress and SSRIs on affect-related behaviors and hippocampal gene expression of BDNF and its receptor TrkB.

\section{Developmental fluoxetine exposure and affective behaviors}

In the present study developmental fluoxetine exposure increased anxiety in non-stressed male offspring, supporting previous literature showing an increase in 
anxiety behavior following perinatal exposure to SSRIs in adult male rodents (Ansorge, Morelli, \& Gingrich, 2008; Ansorge, et al., 2004; Karpova, et al., 2009; Lee, 2009; Noorlander, et al., 2008; Olivier, et al., 2011; Smit-Rigter, et al., 2012). However, in adult male offspring exposed to fluoxetine after prenatal stress there was a significant decrease in anxiety, as measured by the open field test. This supports our previous work showing that postnatal fluoxetine exposure can reverse the effects of maternal prenatal stress on behavior and shows that the actions of earlylife exposure to fluoxetine can markedly differ when using a model of maternal stress/depression, a model which arguably more closely mimics the clinical situation.

We also found that prenatal stress alone decreased escape behaviors of adult male offspring with no effects of developmental flouxetine exposure on depressionrelated behaviors. These findings are in accordance with earlier work in prenatally stressed Sprague-Dawley rat offspring that reported a decrease in escape attempts in the forced swim after prenatal stress, with little effect on immobility (Van den Hove, et al., 2013). Clearly showing that prenatal stress alone can have a significant longterm impact on depression-related behaviors in adult offspring.

We did not find an effect of developmental exposure to fluoxetine on any depression-related measures in the present study. Previous work we have done in adolescent offspring showed that developmental fluoxetine exposure reversed the effect of maternal stress on depression-related behavior, as measured by the FST (Rayen et al 2011). In addition, previous work has shown that developmental fluoxetine treatment, in non-stressed adult offspring, decreased immobility in the forced swim test (Karpova, et al., 2009). Discrepancies between our work and others may are likely due to methodological differences such as the timing and administration method of fluoxetine, age at testing, as well as species differences (rats versus mice). These findings suggest that developmental fluoxetine exposure has very little effect of depression-related behaviors in adult male offspring. However, more work is needed in this area using further tests of depression-related behaviors before firm conclusions can be made about the long-term impact of developmental exposure to SSRIs on depression.

\section{Developmental fluoxetine exposure and hippocampal BDNF signaling}


To further understand the long-term effects of developmental fluoxetine on molecular pathways that may underlie behavioral changes in adult male offspring, we examined hippocampal expression of BDNF, its high-affinity receptor TrkB and related signaling known to be involved in neuronal plasticity. Developmental fluoxetine exposure decreased hippocampus BDNF IV mRNA levels. During adulthood, the BDNF IV transcript is involved in the regulation of stress responses, and in the mechanism of action of antidepressants (Boulle, et al., 2012). Adult use of fluoxetine has been shown to increase BDNF levels (including BDNF IV mRNA levels) in cortico-limbic structures to induce antidepressant and anxiolytic effects in rodents (Martinowich, Manji, \& Lu, 2007). Data from the current study showing that early life exposure to fluoxetine decreases hippocampal BDNF IV mRNA levels suggest that the molecular mechanisms mediating early-life versus adulthood fluoxetine interventions are distinct. This can partly be explained by the fact that during postnatal development, certain populations of neurons express a transient serotonergic phenotype that no longer exists at adulthood, and the modulation of this partial 5-HT system may interfere with the fine-tuning process of neuronal networks (Cases et al., 1998; Gaspar, Cases, \& Maroteaux, 2003). Moreover, fluoxetine interacts with several targets including 5-HT receptors (2A, 2C and 2B) and ion channels (Mostert, Koch, Heerings, Heersema, \& De Keyser, 2008), as well as the 5-HTT. Hence, the distinct patterns of expression of these targetrs in early-life might be determinant in the long-term biological action of perinatal fluoxetine exposure.

The present findings also show that developmental fluoxetine exposure decreased BDNF IX mRNA levels and TrkB mRNA levels in non-stressed male offspring. These findings, together with the observation that developmental fluoxetine exposure increased anxiety-like behavior in non-stressed male offspring, support that the notion that BDNF/TrkB signaling may play an important role in anxiety regulation (Chen et al., 2006; Martinowich, et al., 2007).

\section{Prenatal stress and hippocampal BDNF signaling.}

We also found that prenatal stress exposure further decreased BDNF IV mRNA levels in the hippocampus. This is in line with previous work showing the prenatal stress decreases expression of BDNF in the hippocampus of adult male offspring (Boersma 
et al., 2014). However, others have found minimal or the opposite effect of prenatal stress on hippocampal BDNF signaling in offspring and these discrepancies may be due to the timing, duration and intensity of stress, as well as the species or strain of animals used (Karpova, et al., 2009; Neeley, Berger, Koenig, \& Leonard, 2011; Roceri, Hendriks, Racagni, Ellenbroek, \& Riva, 2002).

Interestingly, a decrease in BDNF in the hippocampus has been reported in post-mortem brain analysis of suicide victims (Dwivedi et al., 2003; Pandey et al., 2008). Rodent models of stress and depression during adulthood also showed a similar decrease of BDNF expression, including reduced levels of BDNF exon IV and exon IX (Fuchikami, Morinobu, Kurata, Yamamoto, \& Yamawaki, 2009; Onishchenko, Karpova, Sabri, Castren, \& Ceccatelli, 2008; Tsankova et al., 2006). BDNF expression is tightly regulated at the level of transcription with differential exon usage, suggesting a crucial role for the various transcripts in different, brainregion-, cell-type- and intracellular location-specific processes and related brain functions (Baj, Leone, Chao, \& Tongiorgi, 2011; Pruunsild, Kazantseva, Aid, Palm, \& Timmusk, 2007).

\section{$\underline{\text { Conclusion and perspectives }}$}

There is an increasing number of children exposed to SSRI medications during development (Cooper, et al., 2007; Oberlander, et al., 2006) and the long-term effects of such an exposure are still to be determined. Here, we show a long-term impact of maternal fluoxetine exposure on anxiety and hippocampal BDNF signaling in adult male offspring that can differ in the presence of maternal prenatal stress. This expands previous work that we, and others, have done exploring the long-term impact of early exposure of SSRIs on neurobehavioral development in male and female offspring, particularly using a model of maternal stress and depression (Ishiwata, Shiga, \& Okado, 2005; Nagano, et al., 2012; Pawluski, 2012; Ine Rayen, et al., 2015; I. Rayen, et al., 2011). Our data support the idea that exposure to SSRI medications during development may have long-term consequences on neurodevelopment and affectrelated behaviors in adulthood, which may be attributed, at least in part, to reprogramming of signaling pathways implicated in neuronal plasticity. 


\section{Acknowledgements}

JLP was funded by a Charge de Recherche position with Fonds de la Recherche Scientifique (FRS-FNRS). The authors report no conflict of interest. 


\section{$\underline{\text { References }}$}

Alahmed, S., \& Herbert, J. (2008). Strain differences in proliferation of progenitor cells in the dentate gyrus of the adult rat and the response to fluoxetine are dependent on corticosterone. Neuroscience, 157(3), 677-682. doi: S0306-4522(08)01253-0 [pii]10.1016/j.neuroscience.2008.08.072

Ansorge, M. S., Morelli, E., \& Gingrich, J. A. (2008). Inhibition of serotonin but not norepinephrine transport during development produces delayed, persistent perturbations of emotional behaviors in mice. J Neurosci, 28(1), 199-207. doi: 28/1/199 [pii]10.1523/JNEUROSCI.3973-07.2008

Ansorge, M. S., Zhou, M., Lira, A., Hen, R., \& Gingrich, J. A. (2004). Early-life blockade of the 5-HT transporter alters emotional behavior in adult mice. Science, 306(5697), 879-881. doi: 306/5697/879 [pii]10.1126/science.1101678

Autry, A. E., \& Monteggia, L. M. (2012). Brain-derived neurotrophic factor and neuropsychiatric disorders. [Research Support, N.I.H., ExtramuralReview]. Pharmacological reviews, 64(2), 238-258. doi: 10.1124/pr.111.005108

Baj, G., Leone, E., Chao, M. V., \& Tongiorgi, E. (2011). Spatial segregation of BDNF transcripts enables BDNF to differentially shape distinct dendritic compartments. Proc Natl Acad Sci U $S$ A, 108(40), 16813-16818. doi: 1014168108 [pii]10.1073/pnas.1014168108

Boersma, G. J., Lee, R. S., Cordner, Z. A., Ewald, E. R., Purcell, R. H., Moghadam, A. A., \& Tamashiro, K. L. (2014). Prenatal stress decreases Bdnf expression and increases methylation of Bdnf exon IV in rats. Epigenetics, 9(3), 437-447. doi: 10.4161/epi.27558

Boulle, F., van den Hove, D. L., Jakob, S. B., Rutten, B. P., Hamon, M., van Os, J., . . . Kenis, G. (2012). Epigenetic regulation of the BDNF gene: implications for psychiatric disorders. Mol Psychiatry, 17(6), 584-596. doi: mp2011107 [pii]10.1038/mp.2011.107

Cases, O., Lebrand, C., Giros, B., Vitalis, T., De Maeyer, E., Caron, M. G., . . Seif, I. (1998). Plasma membrane transporters of serotonin, dopamine, and norepinephrine mediate serotonin accumulation in atypical locations in the developing brain of monoamine oxidase A knock-outs. $J$ Neurosci, 18(17), 6914-6927.

Castren, E., \& Rantamaki, T. (2010). The role of BDNF and its receptors in depression and antidepressant drug action: Reactivation of developmental plasticity. Dev Neurobiol, 70(5), 289297.doi: 10.1002/dneu.20758

Chen, Z. Y., Jing, D., Bath, K. G., Ieraci, A., Khan, T., Siao, C. J., . . . Lee, F. S. (2006). Genetic variant BDNF (Val66Met) polymorphism alters anxiety-related behavior. Science, 314(5796), 140-143. doi: 314/5796/140 [pii]10.1126/science. 1129663

Cooper, W. O., Willy, M. E., Pont, S. J., \& Ray, W. A. (2007). Increasing use of antidepressants in pregnancy. Am J Obstet Gynecol, 196(6), 544 e541-545. doi: S0002-9378(07)00144-5 [pii]10.1016/j.ajog.2007.01.033

Duman, R. S., \& Voleti, B. (2012). Signaling pathways underlying the pathophysiology and treatment of depression: novel mechanisms for rapid-acting agents. [Research Support, N.I.H., ExtramuralResearch Support, Non-U.S. Gov'tReview]. Trends in neurosciences, 35(1), 47-56. doi: 10.1016/j.tins.2011.11.004

Dwivedi, Y., Rizavi, H. S., Conley, R. R., Roberts, R. C., Tamminga, C. A., \& Pandey, G. N. (2003). Altered gene expression of brain-derived neurotrophic factor and receptor tyrosine kinase B in postmortem brain of suicide subjects. Arch Gen Psychiatry, 60(8), 804-815. doi: 10.1001/archpsyc.60.8.80460/8/804 [pii] 
Fuchikami, M., Morinobu, S., Kurata, A., Yamamoto, S., \& Yamawaki, S. (2009). Single immobilization stress differentially alters the expression profile of transcripts of the brain-derived neurotrophic factor (BDNF) gene and histone acetylation at its promoters in the rat hippocampus. Int $J$ Neuropsychopharmacol, 12(1), 73-82. doi: S1461145708008997 [pii]10.1017/S1461145708008997

Gaspar, P., Cases, O., \& Maroteaux, L. (2003). The developmental role of serotonin: news from mouse molecular genetics. Nat Rev Neurosci, 4(12), 1002-1012. doi: 10.1038/nrn1256

Gentile, S. (2004). Clinical utilization of atypical antipsychotics in pregnancy and lactation. Ann Pharmacother, 38(7-8), 1265-1271. doi: 10.1345/aph.1D485aph.1D485 [pii]

Gentile, S. (2005). SSRIs in pregnancy and lactation: emphasis on neurodevelopmental outcome. CNS Drugs, 19(7), 623-633. doi: 1974 [pii]

Gentile, S., Rossi, A., \& Bellantuono, C. (2007). SSRIs during breastfeeding: spotlight on milk-toplasma ratio. Arch Womens Ment Health, 10(2), 39-51. doi: 10.1007/s00737-007-0173-0

Homberg, J. R., Schubert, D., \& Gaspar, P. (2010). New perspectives on the neurodevelopmental effects of SSRIs. Trends Pharmacol Sci, 31(2), 60-65. doi: S0165-6147(09)00201-6 [pii]10.1016/j.tips.2009.11.003

Ishiwata, H., Shiga, T., \& Okado, N. (2005). Selective serotonin reuptake inhibitor treatment of early postnatal mice reverses their prenatal stress-induced brain dysfunction. Neuroscience, 133(4), 893-901. doi: S0306-4522(05)00337-4 [pii]10.1016/j.neuroscience.2005.03.048

Karpova, N. N., Lindholm, J., Pruunsild, P., Timmusk, T., \& Castren, E. (2009). Long-lasting behavioural and molecular alterations induced by early postnatal fluoxetine exposure are restored by chronic fluoxetine treatment in adult mice. Eur Neuropsychopharmacol, 19(2), 97-108. doi: S0924977X(08)00236-8 [pii]10.1016/j.euroneuro.2008.09.002

Kiryanova, V., McAllister, B. B., \& Dyck, R. H. (2013). Long-term outcomes of developmental exposure to fluoxetine: a review of the animal literature. Dev Neurosci, 35(6), 437-439. doi: $10.1159 / 000355709$

Knaepen, L., Rayen, I., Charlier, T. D., Fillet, M., Houbart, V., van Kleef, M., . . Pawluski, J. L. (2013). Developmental fluoxetine exposure normalizes the long-term effects of maternal stress on postoperative pain in Sprague-Dawley rat offspring. PLoS One, 8(2), e57608. doi: 10.1371/journal.pone.0057608

Kristensen, J. H., Ilett, K. F., Hackett, L. P., Yapp, P., Paech, M., \& Begg, E. J. (1999). Distribution and excretion of fluoxetine and norfluoxetine in human milk. Br J Clin Pharmacol, 48(4), 521-527. doi: bcp040 [pii]

Laine, K., Heikkinen, T., Ekblad, U., \& Kero, P. (2003). Effects of exposure to selective serotonin reuptake inhibitors during pregnancy on serotonergic symptoms in newborns and cord blood monoamine and prolactin concentrations. Arch Gen Psychiatry, 60(7), 720-726. doi: 10.1001/archpsyc.60.7.72060/7/720 [pii]

Lee, L. J. (2009). Neonatal fluoxetine exposure affects the neuronal structure in the somatosensory cortex and somatosensory-related behaviors in adolescent rats. Neurotox Res, 15(3), 212-223. doi: $10.1007 / \mathrm{s} 12640-009-9022-4$

Leuner, B., Fredericks, P. J., Nealer, C., \& Albin-Brooks, C. (2014). Chronic gestational stress leads to depressive-like behavior and compromises medial prefrontal cortex structure and function during the postpartum period. PLoS One, 9(3), e89912. doi: 10.1371/journal.pone.0089912

Lisboa, S. F., Oliveira, P. E., Costa, L. C., Venancio, E. J., \& Moreira, E. G. (2007). Behavioral evaluation of male and female mice pups exposed to fluoxetine during pregnancy and lactation. Pharmacology, 80(1), 49-56. doi: 000103097 [pii]10.1159/000103097 
Maccari, S., \& Morley-Fletcher, S. (2007). Effects of prenatal restraint stress on the hypothalamuspituitary-adrenal axis and related behavioural and neurobiological alterations.

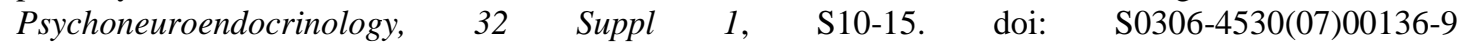
[pii]10.1016/j.psyneuen.2007.06.005

Malm, H. (2012). Prenatal exposure to selective serotonin reuptake inhibitors and infant outcome. Ther Drug Monit, 34(6), 607-614. doi: 10.1097/FTD.0b013e31826d07ea

Martinowich, K., Manji, H., \& Lu, B. (2007). New insights into BDNF function in depression and anxiety. Nat Neurosci, 10(9), 1089-1093. doi: nn1971 [pii]10.1038/nn1971

Misri, S., Reebye, P., Kendrick, K., Carter, D., Ryan, D., Grunau, R. E., \& Oberlander, T. F. (2006). Internalizing behaviors in 4-year-old children exposed in utero to psychotropic medications. Am J Psychiatry, 163(6), 1026-1032.

Molteni, R., Cattaneo, A., Calabrese, F., Macchi, F., Olivier, J. D., Racagni, G., . . . Riva, M. A. (2010). Reduced function of the serotonin transporter is associated with decreased expression of BDNF in rodents as well as in humans. Neurobiol Dis, 37(3), 747-755. doi: S0969-9961(09)00369-6 [pii]10.1016/j.nbd.2009.12.014

Moses-Kolko, E. L., Bogen, D., Perel, J., Bregar, A., Uhl, K., Levin, B., \& Wisner, K. L. (2005). Neonatal signs after late in utero exposure to serotonin reuptake inhibitors: literature review and implications for clinical applications. JAMA, 293(19), 2372-2383. doi: 293/19/2372 [pii]10.1001/jama.293.19.2372

Mostert, J. P., Koch, M. W., Heerings, M., Heersema, D. J., \& De Keyser, J. (2008). Therapeutic potential of fluoxetine in neurological disorders. CNS Neurosci Ther, 14(2), 153-164. doi: CNS040 [pii]10.1111/j.1527-3458.2008.00040.x

Nagano, M., Liu, M., Inagaki, H., Kawada, T., \& Suzuki, H. (2012). Early intervention with fluoxetine reverses abnormalities in the serotonergic system and behavior of rats exposed prenatally to dexamethasone. Neuropharmacology, 63(2), 292-300. doi: 10.1016/j.neuropharm.2012.03.027

Neeley, E. W., Berger, R., Koenig, J. I., \& Leonard, S. (2011). Prenatal stress differentially alters brain-derived neurotrophic factor expression and signaling across rat strains. Neuroscience, 187, $24-35$. doi: S0306-4522(11)00373-3 [pii]10.1016/j.neuroscience.2011.03.065

Noorlander, C. W., Ververs, F. F., Nikkels, P. G., van Echteld, C. J., Visser, G. H., \& Smidt, M. P. (2008). Modulation of serotonin transporter function during fetal development causes dilated heart cardiomyopathy and lifelong behavioral abnormalities. PLOS ONE, 3(7), e2782. doi: 10.1371/journal.pone.0002782

O'Mahony, S. M., Myint, A. M., van den Hove, D., Desbonnet, L., Steinbusch, H., \& Leonard, B. E. (2006). Gestational stress leads to depressive-like behavioural and immunological changes in the rat. Neuroimmunomodulation, 13(2), 82-88. doi: 10.1159/000096090

Oberlander, T. F., Gingrich, J. A., \& Ansorge, M. S. (2009). Sustained neurobehavioral effects of exposure to SSRI antidepressants during development: molecular to clinical evidence. Clin Pharmacol Ther, 86(6), 672-677. doi: clpt2009201 [pii]10.1038/clpt.2009.201

Oberlander, T. F., Papsdorf, M., Brain, U. M., Misri, S., Ross, C., \& Grunau, R. E. (2010). Prenatal effects of selective serotonin reuptake inhibitor antidepressants, serotonin transporter promoter genotype (SLC6A4), and maternal mood on child behavior at 3 years of age. Arch Pediatr Adolesc Med, 164(5), 444-451. doi: 10.1001/archpediatrics.2010.51

Oberlander, T. F., Reebye, P., Misri, S., Papsdorf, M., Kim, J., \& Grunau, R. E. (2007). Externalizing and attentional behaviors in children of depressed mothers treated with a selective serotonin reuptake inhibitor antidepressant during pregnancy. Arch Pediatr Adolesc Med, 161(1), 22-29. 
Oberlander, T. F., Warburton, W., Misri, S., Aghajanian, J., \& Hertzman, C. (2006). Neonatal outcomes after prenatal exposure to selective serotonin reuptake inhibitor antidepressants and maternal depression using population-based linked health data. Arch Gen Psychiatry, 63(8), 898-906.

Oliveira, E., Pinheiro, C. R., Santos-Silva, A. P., Trevenzoli, I. H., Abreu-Villaca, Y., Nogueira Neto, J. F., . . Lisboa, P. C. (2010). Nicotine exposure affects mother's and pup's nutritional, biochemical, and hormonal profiles during lactation in rats. J Endocrinol, 205(2), 159-170. doi: JOE-09-0430 [pii]10.1677/JOE-09-0430

Olivier, J. D., Valles, A., van Heesch, F., Afrasiab-Middelman, A., Roelofs, J. J., Jonkers, M., . . . Homberg, J. R. (2011). Fluoxetine administration to pregnant rats increases anxiety-related behavior in the offspring. Psychopharmacology (Berl). doi: 10.1007/s00213-011-2299-z

Onishchenko, N., Karpova, N., Sabri, F., Castren, E., \& Ceccatelli, S. (2008). Long-lasting depressionlike behavior and epigenetic changes of BDNF gene expression induced by perinatal exposure to methylmercury. J Neurochem, 106(3), 1378-1387. doi: JNC5484 [pii]10.1111/j.14714159.2008.05484.x

Pandey, G. N., Ren, X., Rizavi, H. S., Conley, R. R., Roberts, R. C., \& Dwivedi, Y. (2008). Brainderived neurotrophic factor and tyrosine kinase $\mathrm{B}$ receptor signalling in post-mortem brain of teenage suicide victims. Int $J$ Neuropsychopharmacol, 11(8), 1047-1061. doi: S1461145708009000 [pii]10.1017/S1461145708009000

Pawluski, J. L. (2012). Perinatal selective serotonin reuptake inhibitor exposure: impact on brain development and neural plasticity. Neuroendocrinology, 95(1), 39-46. doi: 10.1159/000329293

Pawluski, J. L., Charlier, T. D., Lieblich, S. E., Hammond, G. L., \& Galea, L. A. (2008). Reproductive experience alters corticosterone and CBG levels in the rat dam. Physiol Behav. doi: S00319384(08)00277-1 [pii]10.1016/j.physbeh.2008.09.004

Pawluski, J. L., Galea, L. A., Brain, U., Papsdorf, M., \& Oberlander, T. F. (2009). Neonatal S100B protein levels after prenatal exposure to selective serotonin reuptake inhibitors. Pediatrics, 124(4), e662-670. doi: peds.2009-0442 [pii]10.1542/peds.2009-0442

Pawluski, J. L., Rayen, I., Niessen, N. A., Kristensen, S., van Donkelaar, E. L., Balthazart, J., . . . Charlier, T. D. (2012). Developmental fluoxetine exposure differentially alters central and peripheral measures of the HPA system in adolescent male and female offspring. Neuroscience. doi: S03064522(12)00652-5 [pii]10.1016/j.neuroscience.2012.06.034

Pereira-Figueiredo, I., Sancho, C., Carro, J., Castellano, O., \& Lopez, D. E. (2014). The effects of sertraline administration from adolescence to adulthood on physiological and emotional development in prenatally stressed rats of both sexes. Front Behav Neurosci, 8, 260. doi: 10.3389/fnbeh.2014.00260

Popa, D., Lena, C., Alexandre, C., \& Adrien, J. (2008). Lasting syndrome of depression produced by reduction in serotonin uptake during postnatal development: evidence from sleep, stress, and behavior. J Neurosci, 28(14), 3546-3554. doi: 28/14/3546 [pii]10.1523/JNEUROSCI.4006-07.2008

Pruunsild, P., Kazantseva, A., Aid, T., Palm, K., \& Timmusk, T. (2007). Dissecting the human BDNF locus: bidirectional transcription, complex splicing, and multiple promoters. Genomics, 90(3), 397-406. doi: S0888-7543(07)00118-8 [pii]10.1016/j.ygeno.2007.05.004

Rampono, J., Proud, S., Hackett, L. P., Kristensen, J. H., \& Ilett, K. F. (2004). A pilot study of newer antidepressant concentrations in cord and maternal serum and possible effects in the neonate. Int $J$ Neuropsychopharmacol, 7(3), 329-334. doi: 10.1017/S1461145704004286S1461145704004286 [pii]

Rayen, I., Gemmel, M., Pauley, G., Steinbusch, H. W., \& Pawluski, J. L. (2015). Developmental exposure to SSRIs, in addition to maternal stress, has long-term sex-dependent effects on hippocampal plasticity. Psychopharmacology, 232(7), 1231-1244. doi: 10.1007/s00213-014-3758-0 
Rayen, I., Steinbusch, H. W., Charlier, T. D., \& Pawluski, J. L. (2013). Developmental fluoxetine exposure and prenatal stress alter sexual differentiation of the brain and reproductive behavior in male $\begin{array}{llll}\text { rat } & \text { offspring. } & \text { Psychoneuroendocrinology. } & \text { doi: }\end{array}$ [pii]10.1016/j.psyneuen.2013.01.007

Rayen, I., Steinbusch, H. W., Charlier, T. D., \& Pawluski, J. L. (2014). Developmental fluoxetine exposure facilitates sexual behavior in female offspring. Psychopharmacology (Berl), 231(1), 123-133. doi: $10.1007 / \mathrm{s} 00213-013-3215-5$

Rayen, I., van den Hove, D. L., Prickaerts, J., Steinbusch, H. W., \& Pawluski, J. L. (2011). Fluoxetine during development reverses the effects of prenatal stress on depressive-like behavior and hippocampal neurogenesis in adolescence. PLoS One, 6(9), e24003. doi: 10.1371/journal.pone.0024003PONE-D-1105904 [pii]

Rivero, O., Sich, S., Popp, S., Schmitt, A., Franke, B., \& Lesch, K. P. (2013). Impact of the ADHDsusceptibility gene CDH13 on development and function of brain networks. [Research Support, NonU.S. Gov'tReview]. European neuropsychopharmacology : the journal of the European College of Neuropsychopharmacology, 23(6), 492-507. doi: 10.1016/j.euroneuro.2012.06.009

Roceri, M., Hendriks, W., Racagni, G., Ellenbroek, B. A., \& Riva, M. A. (2002). Early maternal deprivation reduces the expression of BDNF and NMDA receptor subunits in rat hippocampus. Mol Psychiatry, 7(6), 609-616. doi: 10.1038/sj.mp.4001036

Romijn, H. J., Hofman, M. A., \& Gramsbergen, A. (1991). At what age is the developing cerebral cortex of the rat comparable to that of the full-term newborn human baby? Early Hum Dev, 26(1), 6167.

Smit-Rigter, L. A., Noorlander, C. W., von Oerthel, L., Chameau, P., Smidt, M. P., \& van Hooft, J. A. (2012). Prenatal fluoxetine exposure induces life-long serotonin 5-HT(3) receptor-dependent cortical abnormalities and anxiety-like behaviour. Neuropharmacology, 62(2), 865-870. doi: S00283908(11)00410-2 [pii]10.1016/j.neuropharm.2011.09.015

Smith, J. W., Seckl, J. R., Evans, A. T., Costall, B., \& Smythe, J. W. (2004). Gestational stress induces post-partum depression-like behaviour and alters maternal care in rats. Psychoneuroendocrinology, 29(2), 227-244.

Strackx, E., Van den Hove, D. L., Prickaerts, J., Zimmermann, L., Steinbusch, H. W., Blanco, C. E., . . . Vles, J. S. (2009). Fetal asphyctic preconditioning protects against perinatal asphyxia-induced behavioral consequences in adulthood. Behav Brain Res, 208(2), 343-351. doi: S0166-4328(09)007190 [pii]10.1016/j.bbr.2009.11.040

Stragier, E., Massart, R., Salery, M., Hamon, M., Geny, D., Martin, V., . . . Lanfumey, L. (2014). Ethanol-induced epigenetic regulations at the Bdnf gene in C57BL/6J mice. Molecular psychiatry. doi: $10.1038 / \mathrm{mp} .2014 .38$

Toffoli, L. V., Rodrigues, G. M., Jr., Oliveira, J. F., Silva, A. S., Moreira, E. G., Pelosi, G. G., \& Gomes, M. V. (2014). Maternal exposure to fluoxetine during gestation and lactation affects the DNA methylation programming of rat's offspring: modulation by folic acid supplementation. Behav Brain Res, 265, 142-147. doi: 10.1016/j.bbr.2014.02.031

Tsankova, N. M., Berton, O., Renthal, W., Kumar, A., Neve, R. L., \& Nestler, E. J. (2006). Sustained hippocampal chromatin regulation in a mouse model of depression and antidepressant action. Nat Neurosci, 9(4), 519-525. doi: nn1659 [pii]10.1038/nn1659

Van den Hove, D. L., Blanco, C. E., Aendekerk, B., Desbonnet, L., Bruschettini, M., Steinbusch, H. P., . . . Steinbusch, H. W. (2005). Prenatal restraint stress and long-term affective consequences. Dev Neurosci, 27(5), 313-320. doi: 86711 [pii]10.1159/000086711 
Van den Hove, D. L., Blanco, C. E., Scheepens, A., Desbonnet, L., Myint, A. M., Leonard, B. E., . . Steinbusch, H. W. (2008). Prenatal maternal paroxetine treatment and neonatal mortality in the rat: a preliminary study. Neonatology, 93(1), 52-55. doi: 000106433 [pii]10.1159/000106433

Van den Hove, D. L., Kenis, G., Brass, A., Opstelten, R., Rutten, B. P., Bruschettini, M., . . . Prickaerts, J. (2013). Vulnerability versus resilience to prenatal stress in male and female rats; Implications from gene expression profiles in the hippocampus and frontal cortex. Eur Neuropsychopharmacol. doi: S0924-977X(12)00308-2 [pii]10.1016/j.euroneuro.2012.09.011

Van den Hove, D. L., Steinbusch, H. W., Scheepens, A., Van de Berg, W. D., Kooiman, L. A., Boosten, B. J., . . . Blanco, C. E. (2006). Prenatal stress and neonatal rat brain development. Neuroscience, 137(1), 145-155.

Ward, I. L., \& Weisz, J. (1984). Differential effects of maternal stress on circulating levels of corticosterone, progesterone, and testosterone in male and female rat fetuses and their mothers. Endocrinology, 114(5), 1635-1644.

Weinstock, M. (2008). The long-term behavioural consequences of prenatal stress. Neurosci Biobehav Rev, 32(6), 1073-1086. doi: S0149-7634(08)00034-1 [pii] 10.1016/j.neubiorev.2008.03.002 


\section{Figure Captions}

Figure 1. Mean ( \pm SEM) measure of A) Frequency of central entries, B) Time in the centre, and C) Total distance moved in the open field test (OFT). $n=13-15$ rats per group. ${ }^{*} \mathrm{p}<0.05$; Two-way ANOVA, Fisher LSD post hoc test. NS = no stress, $\mathrm{PNS}=$ prenatal stress, $\mathrm{VEH}=$ vehicle, $\mathrm{FLX}=$ fluoxetine.

Figure 2. Mean $( \pm$ SEM) measure of $A)$ Time in the open areas and B) Total distance moved in the elevated zero maze (EZM). $\mathrm{n}=13-15$ rats per group. *p < 0.05; Two-way ANOVA. NS = no stress, PNS = prenatal stress, VEH = vehicle, FLX = fluoxetine.

Figure 3. Mean $( \pm$ SEM) measure of A) Immobility, B) Mobility, C) Strong mobility in the forced swim test (FST). $\mathrm{n}=13-15$ rats per group. ${ }^{*} \mathrm{p}<0.05$; $*$ p $<$ 0.01; Two-way ANOVA, Fisher LSD post hoc test. NS = no stress, PNS = prenatal stress, $\mathrm{VEH}=$ vehicle, FLX = fluoxetine.

Figure 4. Mean $( \pm \mathrm{SEM})$ plasma corticosterone level $\mathbf{s}(\mathbf{n g} / \mathbf{m l}) \cdot n=5-6$ rats per group. ${ }^{*} \mathrm{p}<0.05$ indicating corticosterone elevated after stress. NS $=$ no stress, PNS = prenatal stress, $\mathrm{VEH}=$ vehicle, FLX = fluoxetine.

Figure 5. Mean ( \pm SEM) hippocampal mRNA expression of A)BDNF IV, B)BDNF IX, and C) TrkB. Data expressed as fold changes as compared to naïve animals (NS VEH) $\mathrm{n}=13-14$ rats per group. *p < 0.05; Two-way ANOVA, Fisher LSD post hoc test. NS = no stress, PNS = prenatal stress, $\mathrm{VEH}=$ vehicle, FLX = fluoxetine. 
A

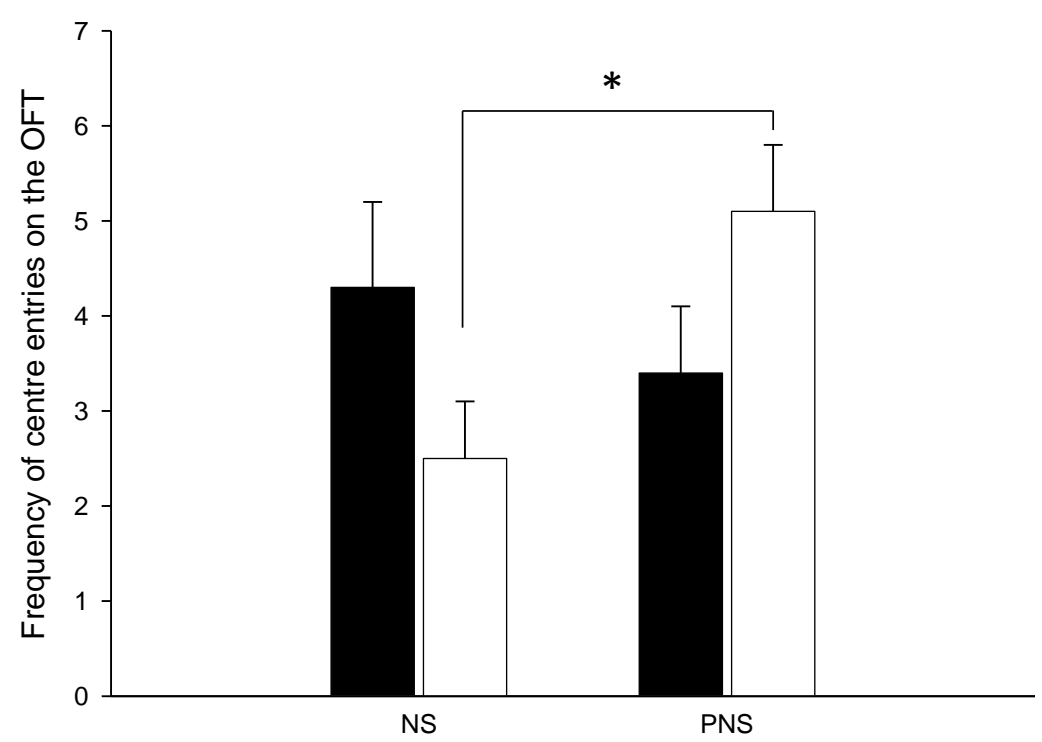

B

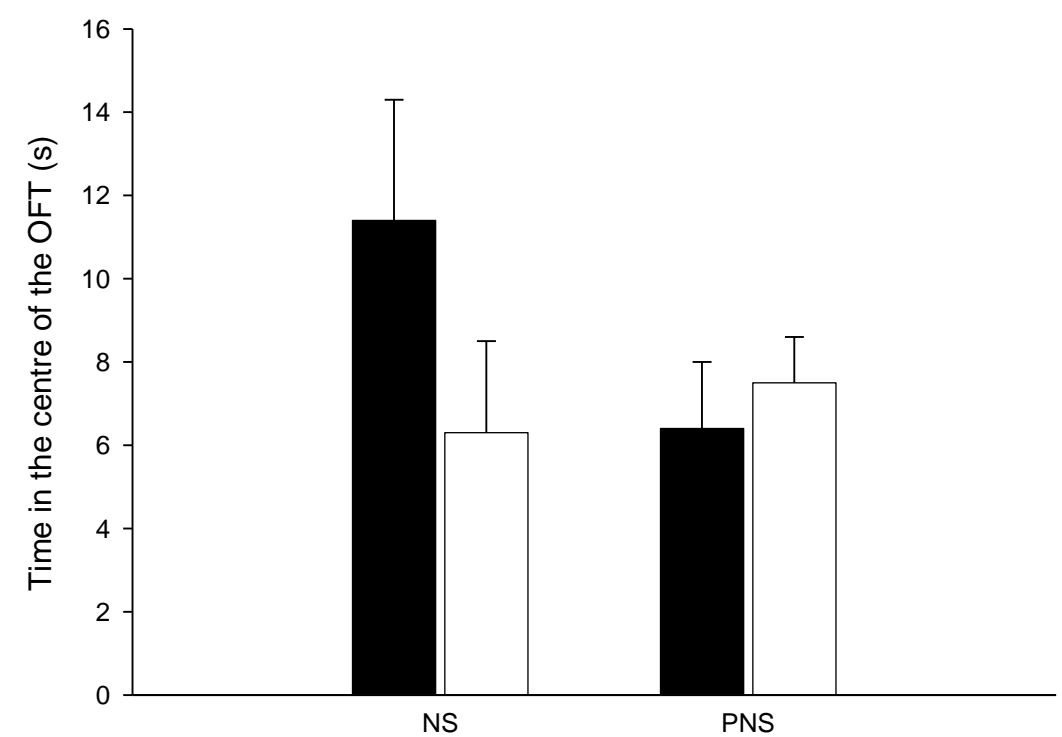

C

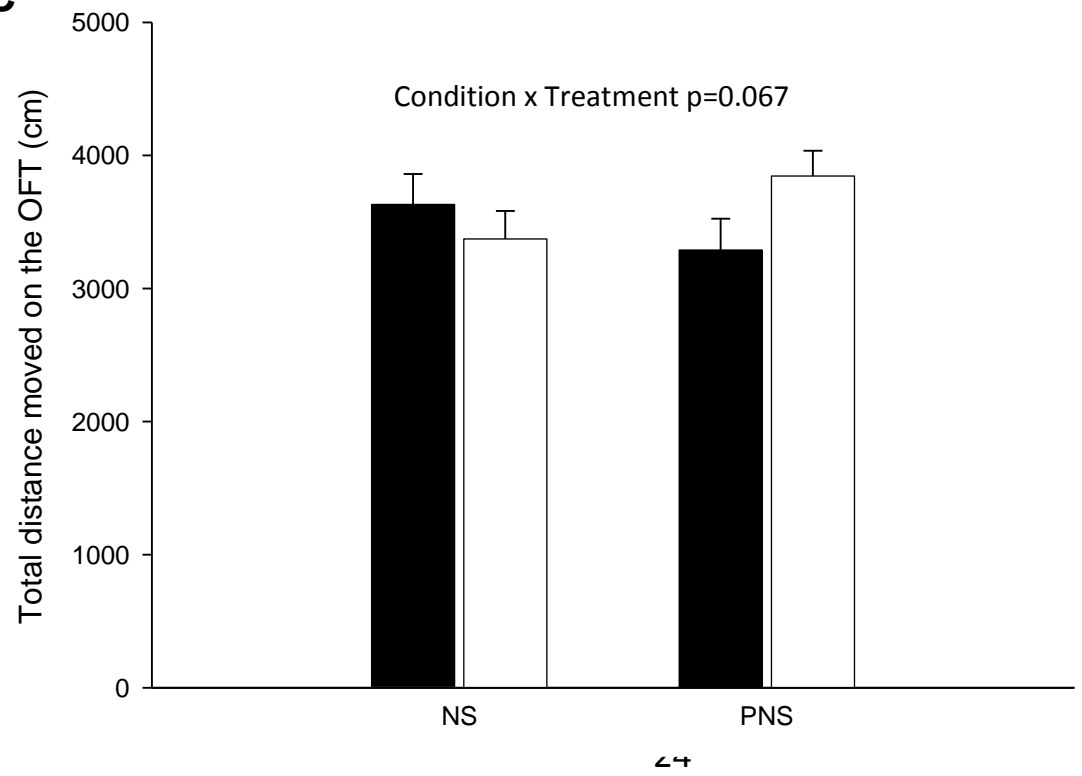


A

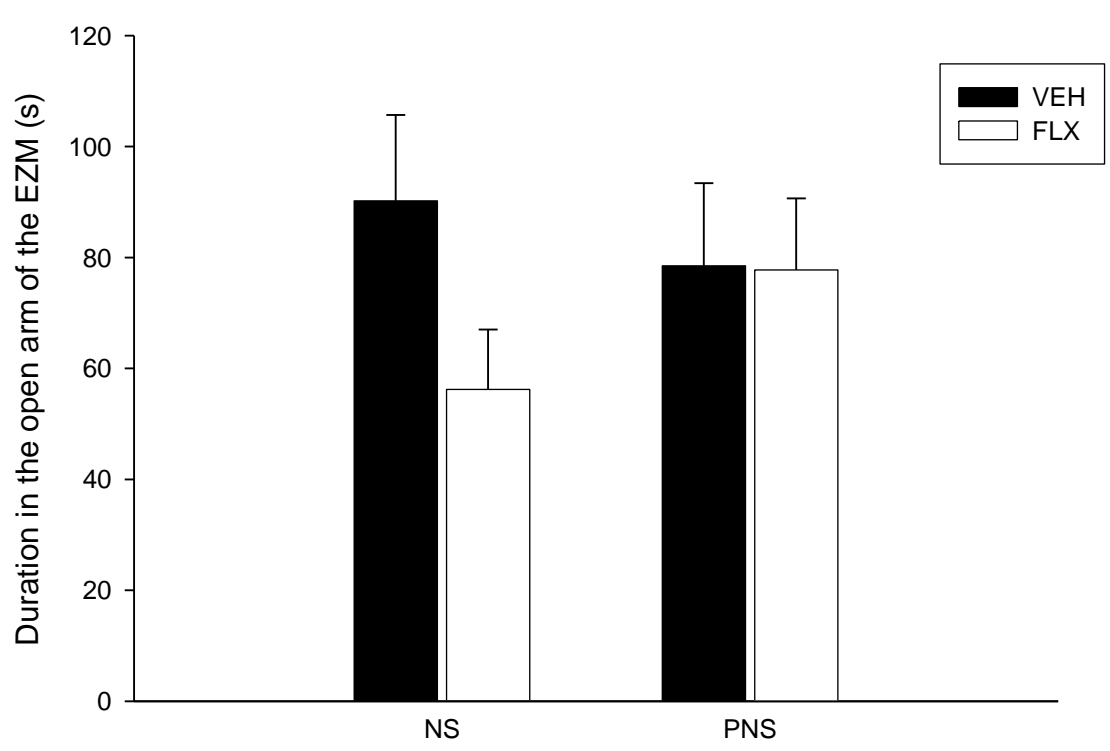

B

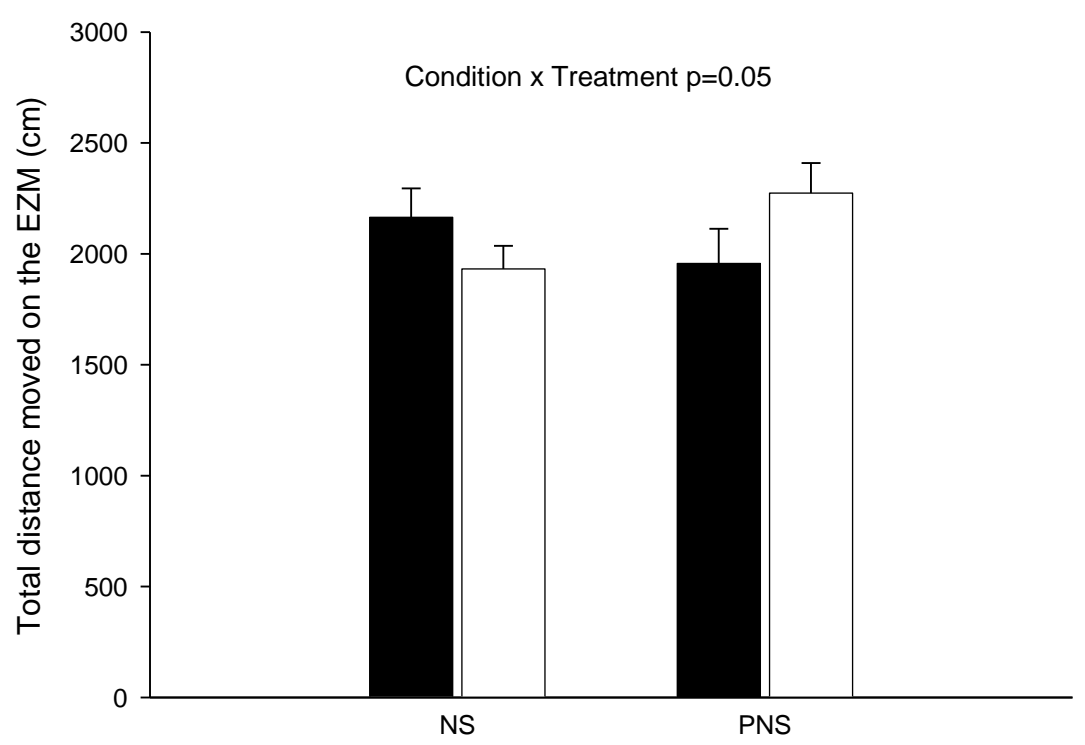

Figure 2 
A

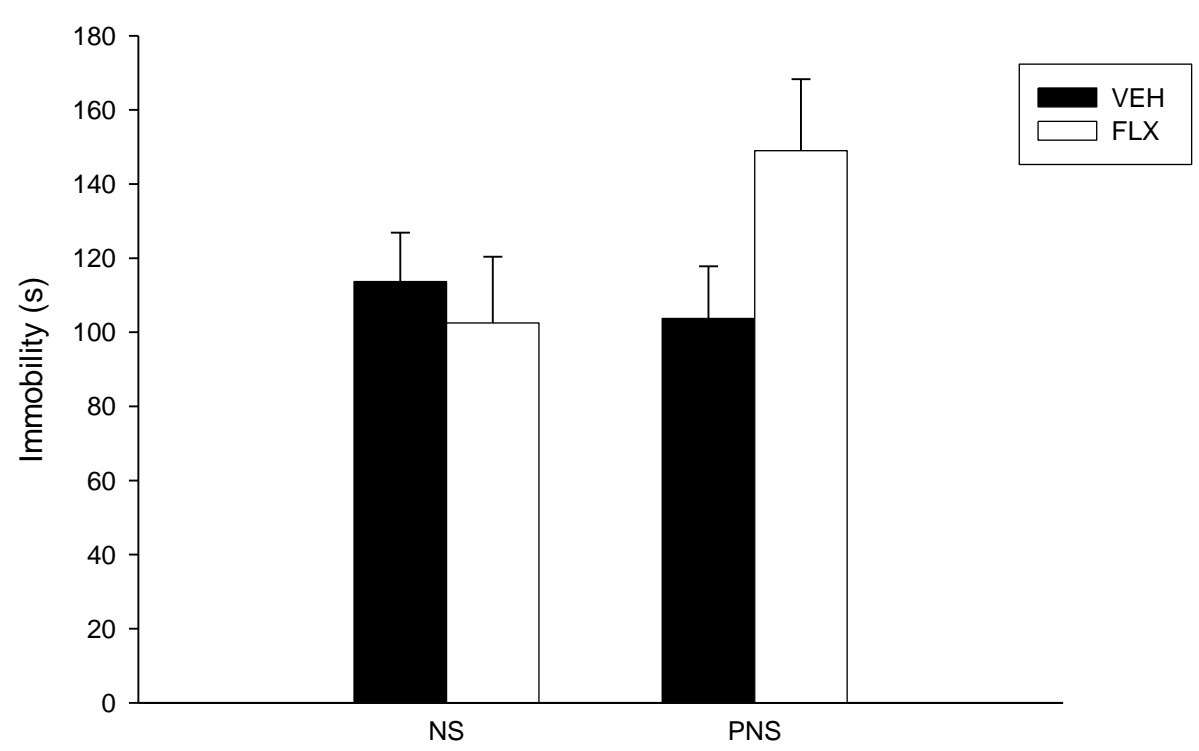

B

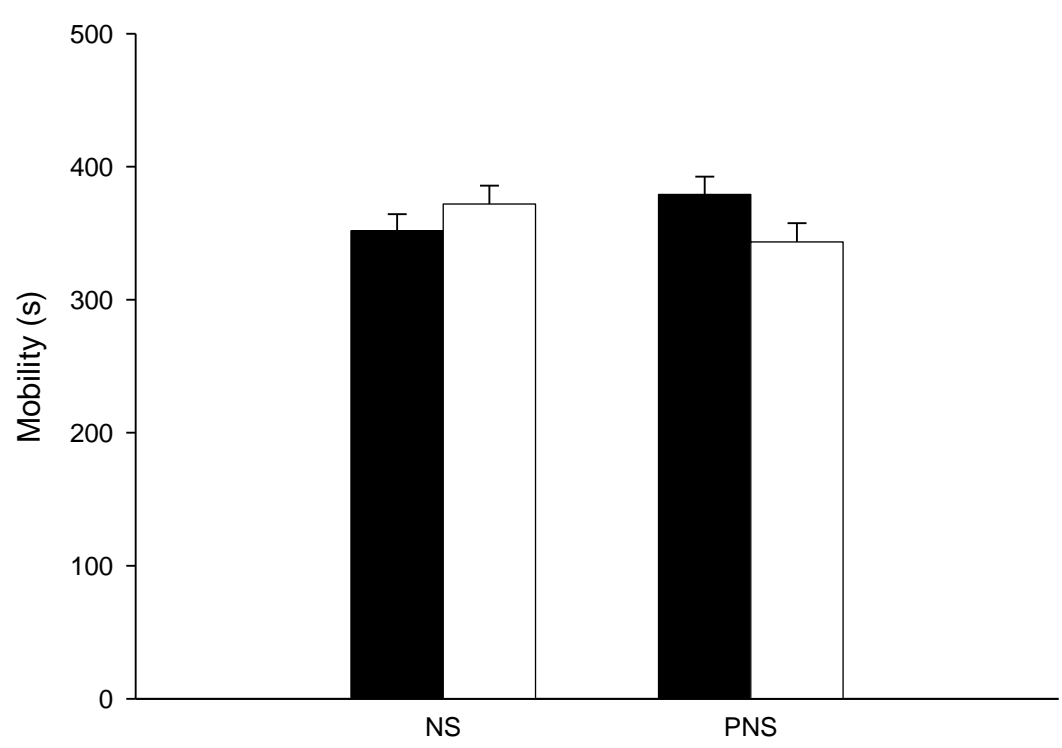

C

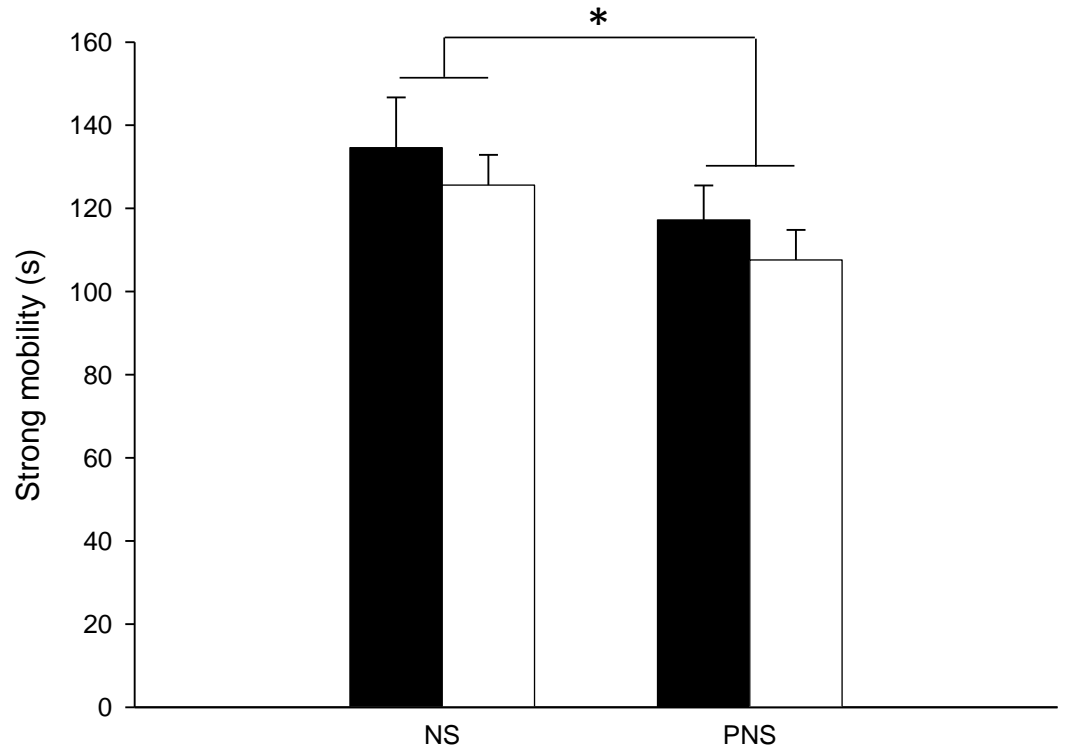

Figure 3 


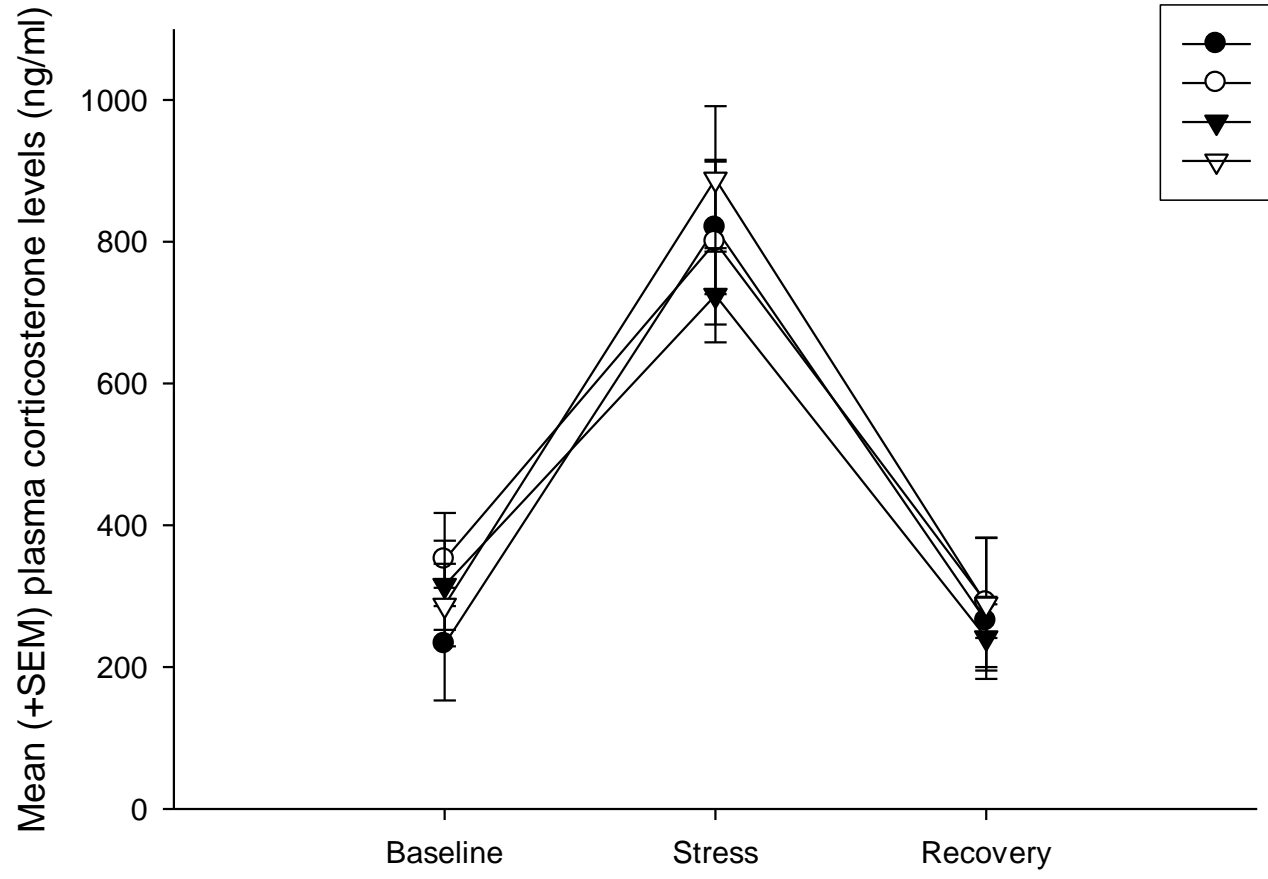

Figure 4 
A

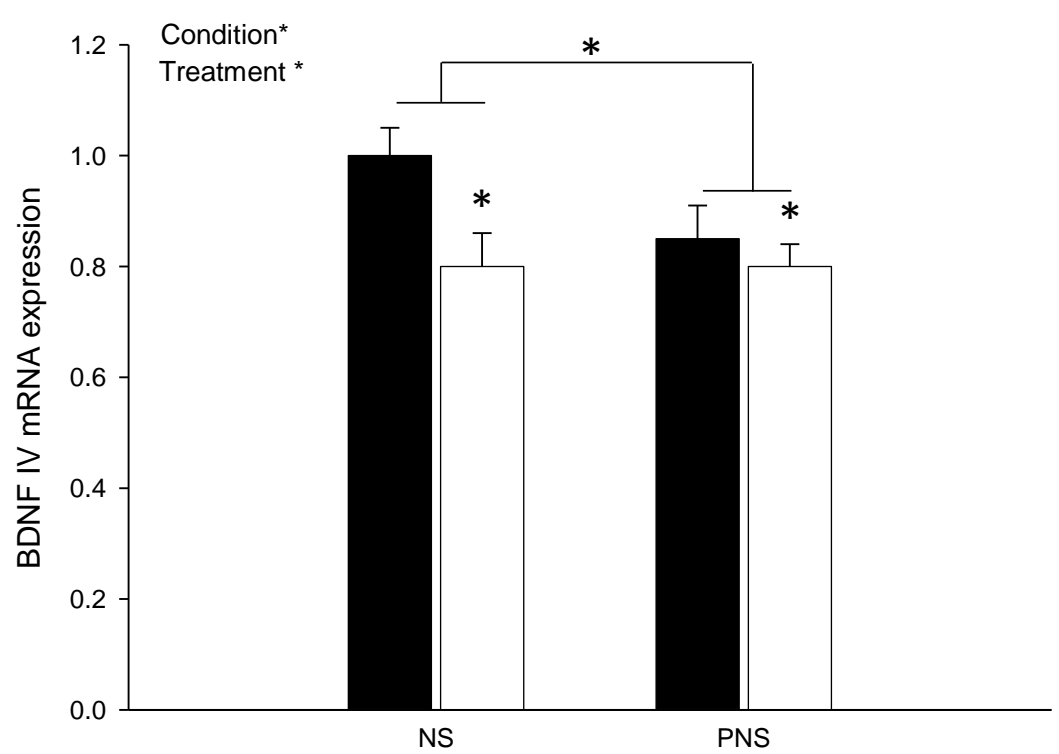

B

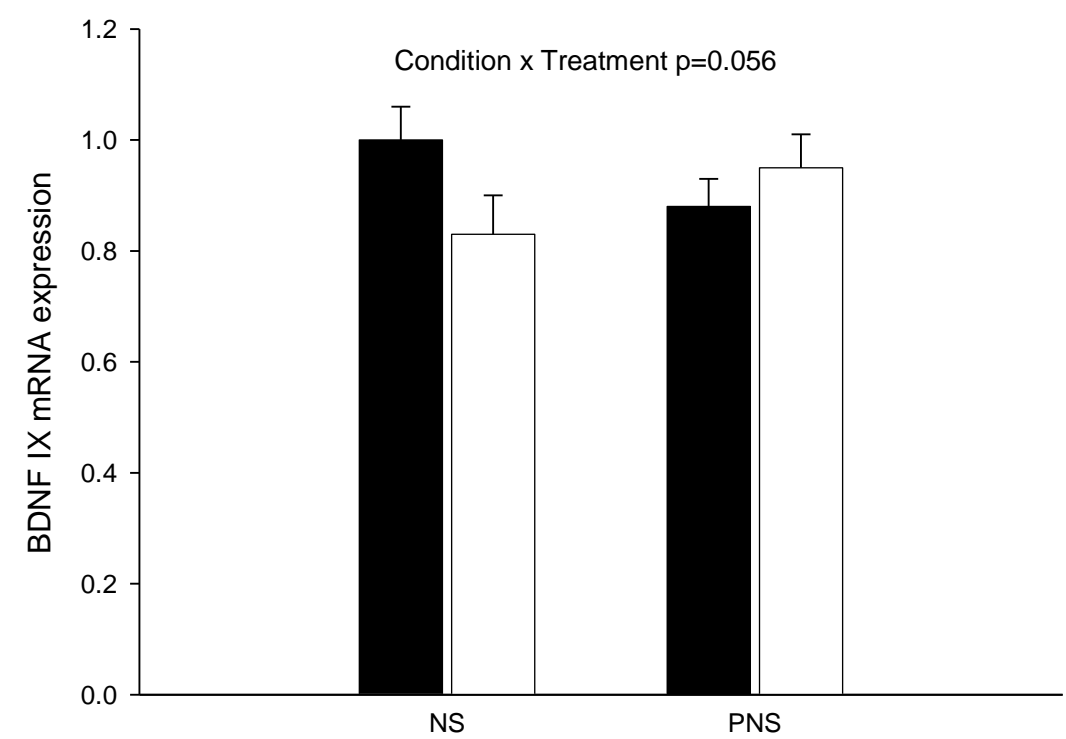

C

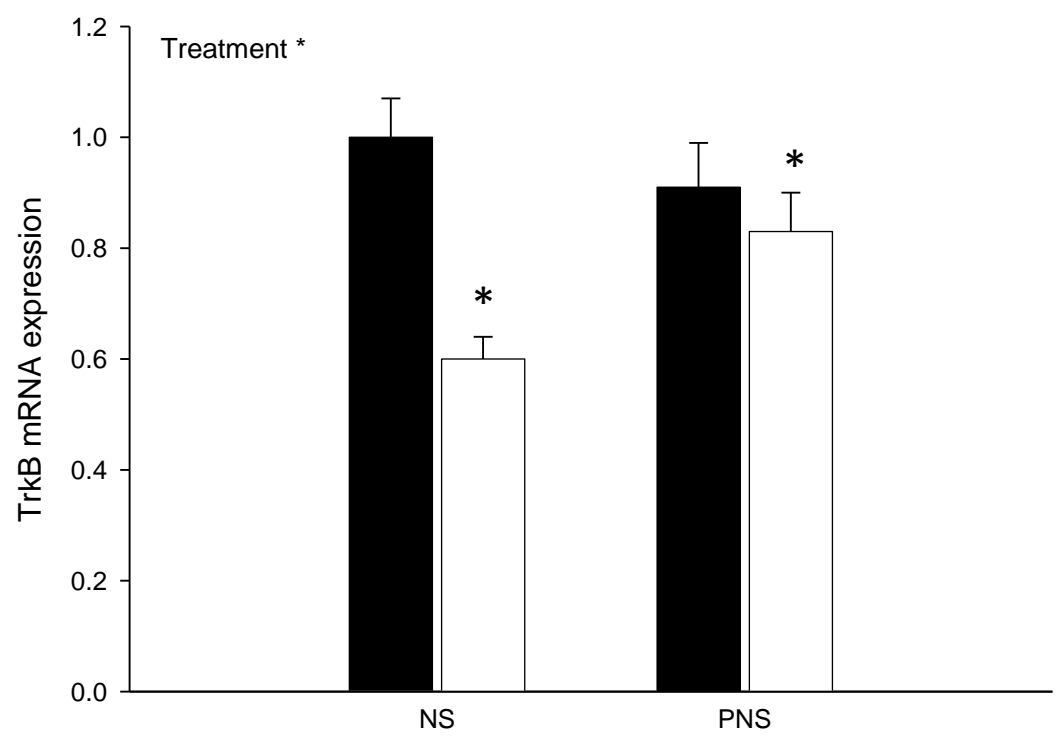

